University of New Hampshire

University of New Hampshire Scholars' Repository

$1-1-2009$

\title{
Issues Related to Incorporating Northern Peatlands into Global Climate Models
}

\author{
Steve Frolking \\ University of New Hampshire - Main Campus, steve.frolking@unh.edu \\ Nigel T. Roulet \\ McGill University \\ David Lawrence \\ National Center for Atmospheric Research
}

Follow this and additional works at: https://scholars.unh.edu/earthsci_facpub

\section{Recommended Citation}

Frolking, S., Roulet, N. and Lawrence, D. (2009) Issues Related to Incorporating Northern Peatlands into Global Climate Models, in Carbon Cycling in Northern Peatlands (eds A. J. Baird, L. R. Belyea, X. Comas, A.S. Reeve and L. D. Slater), American Geophysical Union, Washington, D. C.. doi: 10.1029/ 2008GM000809

This Book Chapter is brought to you for free and open access by the Earth Sciences at University of New Hampshire Scholars' Repository. It has been accepted for inclusion in Earth Sciences Scholarship by an authorized administrator of University of New Hampshire Scholars' Repository. For more information, please contact Scholarly.Communication@unh.edu. 


\title{
Issues Related to Incorporating Northern Peatlands Into Global Climate Models
}

\author{
Steve Frolking \\ Institute for the Study of Earth, Oceans, and Space, University of New Hampshire, Durham, New Hampshire, USA \\ Nigel Roulet \\ Department of Geography and McGill School of the Environment, McGill University, Montreal, Quebec, Canada \\ David Lawrence \\ Climate and Global Dynamics Division, National Center for Atmospheric Research, Boulder, Colorado, USA
}

\begin{abstract}
Northern peatlands cover $\sim 3-4$ million $\mathrm{km}^{2}\left(\sim 10 \%\right.$ of the land north of $\left.45^{\circ} \mathrm{N}\right)$ and contain $\sim 200-400 \mathrm{Pg}$ carbon $(\sim 10-20 \%$ of total global soil carbon), almost entirely as peat (organic soil). Recent developments in global climate models have included incorporation of the terrestrial carbon cycle and representation of several terrestrial ecosystem types and processes in their land surface modules. Peatlands share many general properties with upland, mineral-soil ecosystems, and general ecosystem carbon, water, and energy cycle functions (productivity, decomposition, water infiltration, evapotranspiration, runoff, latent, sensible, and ground heat fluxes). However, northern peatlands also have several unique characteristics that will require some rethinking or revising of land surface algorithms in global climate models. Here we review some of these characteristics, deep organic soils, a significant fraction of bryophyte vegetation, shallow water tables, spatial heterogeneity, anaerobic biogeochemistry, and disturbance regimes, in the context of incorporating them into global climate models. With the incorporation of peatlands, global climate models will be able to simulate the fate of northern peatland carbon under climate change, and estimate the magnitude and strength of any climate system feedbacks associated with the dynamics of this large carbon pool.
\end{abstract}

Carbon Cycling in Northern Peatlands

Geophysical Monograph Series 184

Copyright 2009 by the American Geophysical Union.

10.1029/2008GM000809

\section{INTRODUCTION}

A substantial amount of carbon has accumulated as peat (partially decomposed organic matter) in northern peatlands or mires through the Holocene [Gorham, 1991]. This carbon is situated on what we can think of as two thermodynamic state boundaries that are strongly controlled by the both the climate system and the peatlands themselves. Both of these 
state boundaries have a very strong influence on the fate of peatland carbon; will it remain as peat or be transformed into dissolved or particulate organic matter or into gaseous $\mathrm{CO}_{2}$ or $\mathrm{CH}_{4}$, and if transformed, how rapidly will this occur?

For carbon in many northern peatlands, one of these state boundaries is the solid/liquid phase boundary of water at $0^{\circ} \mathrm{C}$. A significant fraction of northern peatlands are underlain or embedded in permafrost (perennially frozen ground which lies below a surface active layer that seasonally thaws and is generally less than $1 \mathrm{~m}$ thick). In Canada, more than one third of peatlands have permafrost [Tarnocai, 2006]. Smith et al. [2007] estimated that about one third of northern peatlands are in zones of continuous permafrost, with another $40 \%$ of northern peatlands in discontinuous, sporadic, and isolated permafrost zones. Organic carbon in permafrost is relatively inert both physically and biogeochemically while frozen, although laboratory incubations have shown that microbial metabolism and methane production can occur, albeit at very low rates, at temperatures well below $0^{\circ} \mathrm{C}$ [Brouchkov and Fukuda, 2002; Rivkina et al., 2004]. However, any gas produced by this slow metabolic activity will remain within the permafrost because diffusive gas loss from permafrost is negligible [Rivkina et al., 2004, 2007]. A number of studies have established that the old organic matter frozen into permafrost readily decomposes if thawed and that microbial populations that can decompose the organic matter are present and viable in the permafrost [Rivkina et al., 1998, 2004, 2007; Zimov et al., 2006].

Warming in recent decades has been stronger at high northern latitudes than in the rest of the world [Serreze and Francis, 2006], a trend that is projected to continue [Meehl et al., 2007], and this will affect permafrost. Zhang et al. [2006] used a soil physics model to estimate that the area underlain by permafrost in Canada decreased by $\sim 5 \%$ from 1850 to 1990 . Yi et al. [2006, 2007] used the land module of a general circulation model (GCM) to simulate permafrost dynamics under warming for discontinuous and continuous permafrost sites and a range of soil properties. Their results were sensitive to surface cover and soil properties, with surface peat substantially slowing the rate of thaw. Lawrence et al. [2008] also included organic soils in their land surface model; they found that organic soils slowed the rate of permafrost thawing but, nonetheless, projected a significant decline in near-surface permafrost during the 21 st century, using a GCM forced by a strong warming scenario $\left(+7.5^{\circ}\right.$ over Arctic land during 1900-2100). If frozen peat thaws, it will become more readily decomposable, and both it and any decomposition products will become much more susceptible to loss to the atmosphere, leaching or thermokarst erosion. On the other hand, if permafrost develops or expands in a northern peatland (perhaps due to a drying-induced change in peat thermal properties), the peat that freezes will become less susceptible to decomposition or transport.

The second state boundary is biogeochemical, the boundary between oxia and anoxia. Peatland water table depth is the first-order control of the partitioning of the peat profile into aerobic and anaerobic zones. A peatland's water table is generally within $0.5 \mathrm{~m}$ of the peat surface, and this relatively stable, high water table is a result of both the climate and topographic setting and the hydrological properties of the peat itself. Above the water table, the peat is generally oxic, while below the water table, it is generally anoxic. This anoxia affects the decomposition pathways of organic matter, both by slowing its overall rate relative to aerobic decomposition and generating reduced carbon compounds as intermediate- and end-products, including methane $\left(\mathrm{CH}_{4}\right)$, a strong greenhouse gas. The relative proportion of $\mathrm{CO}_{2}$ and $\mathrm{CH}_{4}$ in carbon gas losses from peatlands has important climate consequences due to their different radiative impacts [e.g., Laine et al., 1996; Whiting and Chanton, 2001; Minkkinen et al., 2002; Frolking et al., 2006]. Water table depth is a direct expression of peatland hydrology and is strongly influenced by precipitation, peat hydraulic properties, and a peatland's hydrologic setting within a larger watershed.

A third factor affecting the fate of peat in northern peatlands is locational; almost all peatland carbon is within several meters of the atmosphere, some peat (i.e., that in fens) is also well-integrated into regional hydrological flow paths, and little of the peat is physically isolated in mineral soil aggregates or adsorbed onto mineral surfaces, which can shelter the organic matter from decomposing organisms and reduce its sensitivity to climate change [Davidson and Janssens, 2006; Trumbore and Czimczik, 2008]. In this way peat, though technically soil carbon, is more similar to a vegetation carbon pool. If the peat carbon is mobilized through decomposition or erosion/dissolution, gaseous forms will likely enter the atmosphere, and in some peatland systems, dissolved or particulate organic matter or dissolved inorganic carbon will likely flow out of the peatland and further down the drainage network [e.g., Moore, this volume].

All biogeochemical cycling in vegetation/soil systems is sensitive to climate change through temperature, soil moisture, and other climatic controls on cycling rates and metabolic activity. These direct sensitivities are generally considered to be nonlinear but smoothly varying responses that are relatively small for small changes in climate. The nature of the physical and biogeochemical state boundaries on which much northern peat is poised means that the fate of the large northern peatland carbon pool may be very sensitive to relatively small changes in climate. Northern peatland geographic location ensures that it will experience climate 
change earlier and more rapidly than many other biomes [Christensen et al., 2007], and peat's position at the soil surface means that any response in terms of carbon mobilization and greenhouse gas emissions will rapidly influence the climate system.

Global climate models are needed to provide the best available representations of future climate for assessing the fate of the large pool of carbon in northern peatlands, and those representations will improve if climate feedback effects that can be generated by the dynamics of northern peatlands are included explicitly and if the local climate temperature and moisture conditions of northern peatlands are modeled directly. In other words, climate change projections should be more accurate if the next generation of coupled climatecarbon Earth system models [e.g., Friedlingstein et al., 2006] include northern peatlands as a specific terrestrial biome with some unique properties.

\section{DEVELOPMENTS OF COUPLED CARBON- CLIMATE MODELS, WITH REPRESENTATION OF ECOSYSTEMS}

Over the past several decades, as atmosphere-ocean GCMs have developed in complexity, and as computational power has increased, the land surface representation in these models has gone from a simple bulk surface representation of albedo, aerodynamic roughness, and soil moisture availability to more explicit modeling of the hydrological cycle and to partitioning energy, and water fluxes between the ground and vegetation [Sellers et al., 1997]. Further developments have included layered soils and plant physiological control over canopy stomatal conductance [Sellers et al., 1997; Le Treut et al., 2007; Bonan, 2008].

In the last several years, explicit treatment of the carbon cycle and vegetation dynamics has been incorporated into some GCMs; in these models, the biosphere and atmosphere operate as a coupled system [Cox et al., 2000; Friedlingstein et al., 2006; Le Treut et al., 2007; Randall et al., 2007; Bonan, 2008]. This coupling of the carbon and climate cycles into a single dynamic model has demonstrated the importance of modeling the inherent feedbacks between the climate system and the carbon cycle because they can substantially change the climate response to anthropogenic forcing of greenhouse gas concentrations [e.g., Cox et al., 2000]. The carbon cycle component of these coupled models typically considers a few to about 20 different plant functional types and several plant and soil carbon pools. The plant functional types can be dynamic (i.e., redistribute geographically due to quasicompetitive responses to climate change) or static. Soil carbon pools are spun up to be in approximate equilibrium with the climate forcing (without explicit consideration of peat- lands), and their dynamics during the simulation are controlled by inputs (vegetation productivity and litterfall) and output (decomposition losses), both responding to changing temperature and moisture conditions.

In an early work, Cox et al. [2000] found that carbon cycle feedbacks on the climate system had a positive feedback on warming because climate warming/drying led to the collapse of wet neotropical forest ecosystems and a large net flux of carbon from the land surface to the atmosphere. More recently, an intercomparison was conducted with 11 coupled carbon-climate models (both GCMs and Earth system models of intermediate complexity (EMICs)) using historical anthropogenic greenhouse gas emissions and a future emissions scenario (A2) developed by the Intergovernmental Panel on Climate Change (IPCC) Special Report on Emissions Scenarios (SRES). All model results indicated that increasing $\mathrm{CO}_{2}$ concentrations alone would enhance the rate at which $\mathrm{CO}_{2}$ was taken up by both the land and ocean (a negative feedback), but that the climate change reduced the rate at which $\mathrm{CO}_{2}$ is removed from the atmosphere [Friedlingstein et al., 2006]. However, the model results exhibited substantial variability in their quantification of the strengths of these feedbacks, and in the relative importance of the land and ocean [Friedlingstein et al., 2006]. The models had a range of representations of the terrestrial carbon cycle, some with dynamic vegetation models and some without, but none included peatlands as a possible land cover type. In the recent coupled carbon-climate cycle modeling study of Yoshikawa et al. [2008], the two northern regions identified as having strong system feedbacks, Siberia and western boreal North America, are also regions where a substantial fraction of the landscape is peatlands [e.g., Wieder et al., 2006]. The terrestrial ecosystem component of this coupled carbon-climate system model [Ito and Oikawa, 2002] has general representations of plant and soil functioning, but no specific representation of unique characteristics of peatlands (see section 4 below).

Incorporating peatlands and their carbon cycling into coupled carbon-climate models poses a number of challenges (see section 4 below). Any representation of peatland carbon cycling will have to comply with strict water, energy, and carbon conservation constraints that are imposed by global climate models for climate change integrations. Another requirement is global applicability (e.g., regionally specific solutions should be avoided). There is an additional, more philosophical modeling goal; limit the amount of information, such as surface data sets (e.g., a wetland map) that are prespecified and not permitted to evolve with the rest of the Earth system.

GCMs are computationally demanding, and typical simulations are for periods of hundreds of years or less. This 
is long enough to simulate many issues relevant to peatlands as part of the coupled carbon-climate system (e.g., weather-driven interannual variability in $\mathrm{C}$ balances; impacts on the peatland $\mathrm{C}$ cycle of drought, fire, pollution, harvest or climate change). However, radiocarbon dating of peat cores shows that most sites have been accumulating peat (carbon) persistently for millennia [e.g., Turunen et al., 2002; Yu et al., 2003; Smith et al., 2004]. During this time, the peatlands have not been static; for any peatland, there may have been variations or changes in vegetation cover, hydrological status, peat depth, and peat (C) accumulation rate [e.g., Yu et al., 2003]. At this time, GCM groups are not running continuous simulations for several millennia, though they may be within another decade or less, though probably not as a regular practice. However, several EMICS have been developed that include many GCM processes in simplified or parameterized forms that substantially reduce computation time [Claussen et al., 2002]. These models have been designed for a number of applications, including paleoclimatic reconstructions of the Holocene. Both the CLIMBER-2 model [Brovkin et al., 2002, 2008] and the McGill paleoclimate model [Wang et al., 2005] have done Holocene climate-carbon cycle simulations. Neither explicitly included peatlands.

Spatial resolution of GCM simulations has decreased toward $\sim 100-\mathrm{km}$ grid cells [Le Treut et al., 2007], and representation of subgrid heterogeneity, characterized as a mosaic of tiles, each with a different land cover, is now common though not universal [Pitman, 2003]. Surface energy, water, and carbon fluxes are calculated on each tile before being aggregated and passed to an atmospheric submodel. EMICS have variable spatial resolutions for their representations of the atmosphere, oceans, and land, generally coarser than GCMs. The land representation in CLIMBER-2 was $\sim 10^{\circ}$ latitude $\times 50^{\circ}$ longitude, or $\sim 1000 \mathrm{~km} \times 5000 \mathrm{~km}$ [Brovkin et al., 2002], and for the McGill paleoclimate model, it was $\sim 5^{\circ} \times 5^{\circ}$ [Wang et al., 2005]. Both GCM and EMIC spatial resolutions present a challenge for representing land surface heterogeneity in vegetation cover, soils, topography, biogeochemical processes, and human management, which occur at scales from $<1 \mathrm{~m}$ to $>10^{6} \mathrm{~m}$.

Although the steady growth in computational resources has permitted global models to keep advancing to finer spatial resolution, the resolution is still not fine enough to address fine-scale variability evident in northern peatlands (i.e., variability over scales of 1-10,000 m) [Baird et al., this volume]. For even the highest resolution GCMs, the degree of subgrid surface heterogeneity remains large, especially in the northern high latitudes. To a certain degree, heterogeneity in surface cover has been accounted for by grid cell tiling of vegetation cover. By comparison, soils are treated much more homogeneously. Typically, all vegetation types within a grid cell [for example, up to four plant functional types in a standard configuration for the National Center for Atmospheric Research Community Land Model (CLM)] share the same nonheterogeneous soil column. Wetland distribution is typically either prescribed, based on satellite or other global wetland distribution estimates, or is defined as the fraction of the water table that intersects the surface which is a function of mean grid cell water table depth and surface topography [Gedney et al., 2004; Niu et al., 2005]. Peatlands are typically ignored, or as in Lawrence and Slater [2008] represented without regard to spatial heterogeneity across a grid cell. In global carbon cycle models used in GCMs, there is sometimes no relationship between soil carbon, which is a grid cell level quantity, and wetlands, which is a diagnostic quantity that is a function of the grid cell water balance and surface topography.

\section{NORTHERN PEATLANDS IN THE COUPLED CLIMATE-CARBON SYSTEM}

Northern peatlands, like other terrestrial ecosystems, influence the Earth's climate system through their impact on the land-surface energy balance. Land-surface albedo and roughness are direct functions of vegetation community composition and landscape heterogeneity (e.g., fraction that is open water). The surface energy balance partitioning of the net radiation energy inputs into sensible and latent heat fluxes also depends on the nature of the surface and vegetation cover and on the availability of evaporable water on the vegetation and in the soil.

Northern peatlands, again like other terrestrial systems, also influence the Earth's climate through their impact on the composition of the atmosphere, particularly the greenhouse gases $\mathrm{CO}_{2}$ and $\mathrm{CH}_{4}$. Northern peatlands have been a persistent atmospheric $\mathrm{CO}_{2}$ sink for millennia $\left(0.02-0.03 \mathrm{~kg} \mathrm{C} \mathrm{m}^{-2}\right.$ $\mathrm{a}^{-1}$ over the long term [Gorham, 1995; Tolonen et al., 1992; Smith et al., 2004]). About 250-400 Pg C is sequestered in 3-4 million $\mathrm{km}^{2}$ of northern peatlands [Gorham, 1991; Turunen et al., 2002]. It is not known if, overall, northern peatlands still sequester $\mathrm{C}$ at that rate; multiyear site measurements show a variable annual $\mathrm{C}$ balance and generally a net uptake [Lafleur et al., 2003; Aurela et al., 2002; Roulet et al., 2007; Nilsson et al., 2008].

Northern peatlands are currently also a source of $\sim 10-40$ $\mathrm{Tg} \mathrm{CH} \mathrm{Ca}^{-1}$ [Prather et al., 2001] and, along with tropical wetlands, likely emitted a large fraction of global total methane flux through the Holocene, when the anthropogenic sources that dominate current budgets were small to negligible. Peatland methane emissions are strongly related to hydrology [Bubier et al., 1995; Waddington et al., 1996; 
MacDonald et al., 1998], net primary productivity [Whiting and Chanton, 1993; Waddington et al., 1996], and vegetation composition [Bubier, 1995; King et al., 1998; Joabsson et al., 1999]. All of these factors are interrelated, and they interact to control methane fluxes [e.g., Treat et al., 2007], so predictions based on any one factor inevitably have a limited range of application.

Frolking and Roulet [2007] have shown that the net fluxes of $\mathrm{CO}_{2}$ and $\mathrm{CH}_{4}$ from northern peatlands through the Holocene were large enough to influence the global climate system. They estimated a contemporary radiative forcing impact of about $-0.4 \mathrm{~W} \mathrm{~m}^{-2}$ (a net cooling) as a result of the effect that peatland development through the Holocene has on the current atmospheric burdens of $\mathrm{CO}_{2}$ and $\mathrm{CH}_{4}$. Current peatland carbon content, accumulated over the past $\sim 10,000$ years, is roughly equivalent to $100-200$ ppmv $\mathrm{CO}_{2}$ in the atmosphere $(\sim 25-50 \%)$, so simulations of Holocene climate dynamics should include a representation of peatlands as a significant component of the global carbon cycle.

Peatlands are generally viewed as sluggish, slowly evolving, self-stabilizing ecosystems [e.g., Charman, 2002] and, under relatively stable climatic conditions, their large carbon pool as relatively inert [e.g., Clymo, 1984]. However, relatively rapid changes in peatland vegetation and net carbon fluxes are possible; these changes include fire burning for hours to months [Turetsky et al., 2004], industrial harvest occurring over weeks to years [e.g., Tuittila et al., 2003; Petrone et al., 2001], permafrost thaw/collapse occurring over years to decades [e.g., Camill et al., 2001; Malmer et al., 2005; Johansson et al., 2006; Wickland et al., 2006], decadal changes in vegetation composition-including tree encroachment attributed to gradual drying and $\mathrm{N}$-deposition as well as internal or autogenic processes [e.g., Gunnarsson et al., 2000], drainage/drought impacts occurring over years to decades [e.g., Laine et al., 1995; Minkkinen et al., 1999, 2002], and pollution inputs and related vegetation changes over years to decades [e.g., Bobbink et al., 1998]. All of these factors are likely to change over the coming century with changes in climate, atmospheric chemistry, and human activity. Through destabilization, disturbance, or other changes in ecosystem structure or physiology, the carbon in peatlands can be released to the atmosphere as $\mathrm{CO}_{2}, \mathrm{CO}$, and/or $\mathrm{CH}_{4}$ or can transfer as dissolved organic carbon (DOC) and/or particulate organic carbon downstream. Even without disturbance/destabilization, the net carbon balance of northern peatlands is expected to change with climate change, but the nature, magnitude, and even the sign of that change is uncertain [Moore et al., 1998; Gorham, 1991]. Since changing fluxes of $\mathrm{CO}_{2}$ and $\mathrm{CH}_{4}$ from northern peatlands will affect the climate system, the best way to model these feed- back loops is to incorporate peatlands directly into a climate model.

\section{NORTHERN PEATLAND ECOSYSTEM PROPERTIES THAT WILL REQUIRE NEW CLIMATE MODEL DEVELOPMENTS}

Wetlands differ from other terrestrial landscapes due to the presence of water at or near the soil surface for most or all of the year, soils that frequently have limited oxygen content, and specialized plants that are able to grow in these conditions. Peatlands (or mires, in Europe) are a subclass of wetlands that have substantial accumulations of partially decomposed plant detritus at the soil surface [Charman, 2002; Rydin and Jeglum, 2006; Wieder and Vitt, 2006; Mitsch and Gosselink, 2007]. Modeling peatland carbon cycling, as a stand-alone model or within a regional ecosystem/biogeochemistry model or GCM, requires special attention to several unique peatland properties related to soil physics and hydrology, landscape spatial heterogeneity, vegetation physiology, and ecosystem biogeochemistry (Table 1).

\subsection{Soil}

To be classified as a peatland, there must be a surface layer of organic soil or peat that is at least $0.3 \mathrm{~m}$ (United States) or $0.4 \mathrm{~m}$ (Canada) thick; typically, peat depths are one to several meters but may exceed $10 \mathrm{~m}$. This peat is predominantly organic matter, with a small mineral component $(<30 \%$, and often only a few percent), and thus peat physical properties, e.g., pore size distribution, bulk density, thermal and hydraulic conductivities, differ significantly from those of mineral soils [e.g., Boelter, 1964, 1969; Walmsey, 1977; Hillel, 1980]. Peat ash-free bulk densities are typically 0.02 to $0.35 \mathrm{~g} \mathrm{~cm}^{-3}$ [e.g., Walmsey, 1977]; based on extensive sampling in western Canada [Zoltai et al., 2000], shrubby and treed fens generally have a median of bulk density of $0.1-0.15 \mathrm{~g} \mathrm{~cm}^{-3}$, while bogs and open fens have a median of bulk density of $0.06-0.1 \mathrm{~g} \mathrm{~cm}^{-3}$ [Zicheng Yu, personal communication]. Peat porosities are $>0.8 \mathrm{~cm}^{3} \mathrm{~cm}^{-3}$ [Verry and Boelter, 1978]. Mineral soil bulk densities are typically $1.1-1.6 \mathrm{~g} \mathrm{~cm}^{-3}$, and porosities are typically $0.3-0.6 \mathrm{~cm}^{3} \mathrm{~cm}^{-3}$ [e.g., Hillel, 1980].

The low bulk density and high porosity of peat give it significantly different thermal properties than mineral soils [Hillel, 1980], a factor that can be important in permafrost development and decay [Zoltai, 1993]. Peat heat capacity and thermal conductivity are highly dependent on moisture content [Farouki, 1981]. Kettridge and Baird [2007] developed peat-specific predictive relationships of vertical variations in heat capacity through the unsaturated zone of poorly 
Table 1. Peatland Characteristics That Will Require Model Development for Inclusion in GCMs ${ }^{\mathrm{a}}$

\begin{tabular}{|c|c|}
\hline Peatland Characteristic & Modeling Issues \\
\hline Thick organic soils (section 4.1) & $\begin{array}{l}\text { Thermal and hydraulic properties differ from mineral soils, and can be more variable } \\
\text { both vertically and horizontally, e.g., saturated hydraulic conductivity can vary by } \\
\text { orders of magnitude in a single vertical peat profile. } \\
\text { Appropriate soil depth and layering may differ from current formulations appropriate } \\
\text { for mineral soils. } \\
\text { Soil profile is inherently dynamic over moderate timescales (decades or longer), with- } \\
\text { out disturbance or erosion, including changes in soil thickness and soil hydraulic } \\
\text { properties as a function of net peat accumulation, changes in vegetation composi- } \\
\text { tion, and peat decomposition } \\
\text { Peat properties are partially determined by overlying vegetation, creating stronger link } \\
\text { between vegetation and soils than is typical for GCMs. }\end{array}$ \\
\hline Fine-scale spatial heterogeneity (section 4.2) & $\begin{array}{l}\text { Northern peatlands have significant variability in microtopography, vegetation, and } \\
\text { water table depth over scales of meters to kilometers. }\end{array}$ \\
\hline Abundant nonvascular plant cover (section 4.3) & $\begin{array}{l}\text { Nonvascular plants have different physiology and phenology than vascular plants } \\
\text { currently modeled. }\end{array}$ \\
\hline Anaerobic biogeochemistry (section 4.4 ) & $\begin{array}{l}\text { Carbon and nitrogen cycle in ways and at rates not characteristic of drained mineral } \\
\text { soils. }\end{array}$ \\
\hline Unique disturbance characteristics (section 4.5) & $\begin{array}{l}\text { Peatlands burn, but little is known about peatland recovery after fire. } \\
\text { Thermokarst dynamics and erosion in permafrost/peat soils generates major changes } \\
\text { in surface characteristics; this is not currently modeled in GCMs. }\end{array}$ \\
\hline
\end{tabular}

${ }^{\text {a See discussion in section } 4 .}$

decomposed Sphagnum peat and between peat thermal conductivity and heat capacity.

Most land surface models in GCMs use some variant of Richards' equation for modeling soil water dynamics [e.g., Cox et al., 1999], and the required hydraulic parameters (saturated hydraulic conductivity, porosity, specific yield) and functions relating soil water content to matric potential and unsaturated hydraulic conductivity come from parameterizations developed as functions of soil texture [e.g., Clapp and Hornberger, 1978]. Peatland soils require new parameterizations, and some work has been done on this [e.g., Letts et $a l ., 2000]$. One particular challenge is that peats often have a very steep decline in hydraulic conductivity (often more than two orders of magnitude) in the top tens of centimeters of peat [e.g., Paavilainen and Päivänen, 1995]; this can pose numerical problems in solving Richard's equation for the relatively coarse vertical representation of soils common in GCMs. Pauwels and Wood [1999a, 1999b] incorporated a moss (organic) soil layer into a land-surface energy balance model, the type of model that would be a land-surface modeling scheme in a GCM. The addition of a moss layer improved model simulations of soil temperature and moisture in boreal forest stands with thick organic horizons; the model was not tested against peatland data. Beringer et al. [2001] incorporated a moss and lichen layer into the soil representation of a GCM land surface model. This surface layer enhanced soil infiltration and insulated the soil, making it cooler in summer and warmer in winter. Moss and lichen metabolism and carbon cycling were not modeled. In their work on incorporating the thermal and hydrologic influences of organic soils into a global climate model, Lawrence and Slater [2008] used data on soil C content of the upper $1.5 \mathrm{~m}$ of soil from the Global Soil Data Task [2000], available at $1^{\circ} \times 1^{\circ}$ resolution, to derive a gridded soil carbon data set. The soil $\mathrm{C}$ was distributed over seven soil layers representing the top $1.38 \mathrm{~m}$ of the soil, with a prescribed soil carbon density profile. The original field data for this database come from $\sim 21,000$ soil profiles [Tempel et al., 1996], or about 1 profile per $6000 \mathrm{~km}^{2}$ of the earth's ice-free land surface. The approach of Lawrence et al. [2008] is acknowledged to be a first attempt at representing the physical influence of organic-rich soil (of which peatlands are a particular class) in the climate system. The coarse resolution of the source, and regridding of the data, meant that the organic matter was effectively spread over the grid cell and that the depth of the "peatlands," which typically would occupy only a fraction of a grid cell, was shallower than many observed peat profiles. More importantly, this approach did not fully address peatland carbon cycling because bryophytes were not represented (see section 4.3 below), and the soil carbon pools were fixed in time and space.

GCMs that include ecosystems and a carbon cycle require initialization of the vegetation cover and vegetation and soil carbon stocks; this is typically done by "spinning up" the model, that is, by running the model with a fixed or regularly repeating climate pattern until the soil and vegetation carbon 
pools reach quasi-steady state [e.g., Thornton and Rosenbloom, 2005]. This steady state is determined over the longest time period of the initialization climate data, so seasonal and interannual variability might still occur with a 20 -year climate file, but variability on time-scales longer than 20 years would be minimal [Thornton and Rosenbloom, 2005]. However, it seems that northern peatlands can be still accumulating carbon as peat $\sim 5000$ to 10,000 years after initial formation [e.g., Roulet et al., 2007; Nilsson et al., 2008], and many may not have reached steady state. This ongoing accumulation is slow, $0.03 \mathrm{~kg} \mathrm{C} \mathrm{m}^{-2} \mathrm{a}^{-1}$ corresponds to $0.3 \mathrm{~mm}$ $\mathrm{a}^{-1}$ of peat with a bulk density of $100 \mathrm{~kg} \mathrm{~m}^{-3}$, assuming $0.5 \mathrm{~kg}$ $\mathrm{C}$ per $\mathrm{kg}$ peat. This timescale is longer, but not unreasonably longer, than the approximately 3000-year spin up timescale of the Biome-BGC carbon-nitrogen cycle model [Thornton and Rosenbloom, 2005]. Thornton and Rosenbloom [2005] show that the approximately 3000 -year spin-up to equilibrium can be reduced by up to $73 \%$ by implementing an accelerated spin-up algorithm. If such an algorithm can be adapted so that it is applicable to peat accumulation, and also considering the ongoing increases in computing capacity, the long peat accumulation timescale would no longer be so daunting.

In the meantime, this slow approach to steady state may not compromise a GCM initialization algorithm. In a simple peat accumulation model, the surface or acrotelm peat (the top $0.3-0.5 \mathrm{~m}$ ), which is the portion of the peat that has the most dynamic seasonal water and carbon cycling, reaches equilibrium much more rapidly, and the slow long-term accumulation happens in the deeper, less dynamic anaerobic zone or catotelm [Clymo, 1984]. Belyea and Baird [2006] argue that peatlands are complex adaptive systems and that the acrotelm is probably never really in steady state; however, from the practical point of view of initializing a peatland for a GCM, it may approach steady state if forced for millennia by a steady climate. The catotelm has only minimal direct interaction with the atmosphere and short-term climate system. This would change only in the case of a major disturbance (e.g., fire, or anthropogenic activity like harvest or draining) that exposed the catotelm to the atmosphere. Long-term peat accumulation will also be relevant in applications of EMICS to Holocene climate dynamics, but is not yet considered in those models [e.g., Brovkin et al., 2002, 2008; Wang et al., 2005].

\subsection{Hydrology and Landscape Spatial Heterogeneity}

As with all other ecosystems, soil temperature and moisture play an important role in peatland $\mathrm{C}$ cycling. However, in peatlands, the role of water is a dominant one. The excess amount of water stored in peatlands controls the predominantly anoxic conditions that reduce decomposition, so that net ecosystem production is persistently positive (i.e., a $\mathrm{CO}_{2}$ sink). Methane, an end-product of anoxic decomposition, is an important greenhouse gas. Hydrology plays a key role in the relative strength of peatlands as a $\mathrm{CO}_{2}$ sink and as a $\mathrm{CH}_{4}$ source and thus on peatland net climate impact. Hence, it is necessary to understand and simulate the hydrology of peatlands to be able to explain and simulate their carbon exchanges.

Peatlands are unique ecosystems in the degree to which they influence their own hydrology. Because the accumulation of meters of peat occurs over millennia, it becomes the substrate that controls the position of the water table and the moisture condition for plants. Due to the near-surface decomposition and collapse of the original plant material, a peat profile develops a stratification with less decomposed fibric peat, with large pores and low density, near the surface, and more decomposed, relatively high-density peat with finer pores deeper in the profile. This transition from less to more decomposed peat, with accompanying large changes in hydraulic properties, occurs over several tens of centimeters around the long-term average water table position. This characteristic, along with the balance and source of inputs and outputs of water, ultimately control structure and function of peatlands. The tight coupling of peat structure and function and peatland hydrology has led Belyea and Baird [2006] to suggest peatlands be considered complex adaptive systems, with important internal dynamic feedbacks governing their development and behavior. The significance of the very steep changes in properties and the existence of a near surface, hydrologically "active" layer, or acrotelm, and a deeper, hydrologically much less active layer, the catotelm [Ingram, 1978] has been recognized for a long time [Clymo, 1984; Charman, 2002; Rydin and Jeglum, 2006]. In ombrotrophic peatlands the peat surface accumulates to an elevation above the local topography, and the water supply is only by atmospheric inputs, while minerotrophic peatlands receive small to large quantities of water that has been in contact with the mineral sediments either beneath or adjacent to a peatland. Peatlands span a gradient along this water/nutrient supply axis [Vitt, 2006], but for the purposes of simulation, the functional structure of peatlands and the biogeochemistry of carbon cycling the division between the ombrotrophic "bog"-like systems and minerotrophic "fen"like systems may be sufficient as a first approximation [e.g., Frolking et al., 2001].

Simulating the hydrology of a peatland to determine the position of the water table and the distribution of moisture above the water table represents a challenge even in the case of individual peatlands. There have been models of peatland hydrology, but these have been primarily for estimating the discharge from peatlands and have been based on relatively 
simple empirical functions [e.g., Guertin et al., 1987; Verry et al., 1988]. There has also been a very long tradition of modeling peatland drainage for forestry and agricultural practices [e.g., Konyha et al., 1988]. However, there have been few modeling attempts to simulate peatland hydrology that are appropriate for climate and carbon simulations. One example is the recent work of Borren and Bleuten [2006], who combined the MODFLOW groundwater model with a dynamic digital elevation model (driven by peat accumulation) and a paleoclimate time series to simulate the coupled carbon and water cycles through the Holocene of an $800-\mathrm{km}^{2}$ peatland complex in the West Siberian Lowlands. Peat hydraulic properties were constant unless the simulated peatland switched from fen to bog, which depended on water fluxes and assumed nutrient availability, so the primary feedback between peatland development and hydraulic properties was through the digital elevation model. They found that long-term peat accumulation and lateral expansion were limited by hydrology and that model sensitivity to hydrological parameters was high.

Comer et al. [2000] and Letts et al. [2000] modified the Canadian Land Surface Scheme (CLASS) for the inclusion of peat and the simulation of the position of the water table. The revised CLASS was quite successful at simulating the moisture dynamics in fens and was able to reproduce the evapotranspiration losses for fens and bogs reasonably well [Comer et al., 2000], but failed to reproduce the runoff from bogs. CLASS does not include subsurface lateral flow, and this is the most important runoff pathway in bogs [e.g., Verry et al., 1988; Evans et al., 1999]. Yurova et al. [2007] and Yurova and Lankreijera [2007] have combined a soil organic matter model (ROMUL) and a surface climate-ecosystem model (GUESS) to simulate the coupling of hydrology and carbon dynamics in a Swedish northern fen. Others have developed one-dimensional surface hydrological models that would be suitable for climate simulations but few have been evaluated for multiple years [e.g., Weiss et al., 2006].

However, the problem becomes significantly more difficult when a peatland has either significant internal redistribution of water (i.e., spatial heterogeneity within a peatland) or when it receives a meaningful proportion of the water required to maintain a high water table from beyond its boundaries (e.g., groundwater inputs). Spatial heterogeneity within northern peatlands is extremely common [e.g., Couwenberg and Joosten, 2005] and may play an important role in the peatland water and carbon balance. Sonnentag et al. [2008] modified the Boreal Ecosystem Productivity Simulator for peatland hydrology, and ran it in a version of the TerrainLab model to simulate the effect of the mesoscale spatial variability (on the order of $1 \mathrm{~km}$ ) on the hydrology and net ecosystem productivity of a peatland. They found a strong correlation between the spatial variability of simulated evapotranspiration (ET) and gross primary productivity (GPP), and that ignoring the effect of spatial variability systematically underestimated ET and GPP by $\sim 10 \%$. If external water inputs to a peatland are significant, the peatland needs to be simulated in the context of its hydrological setting within the surrounding watershed. If the input of water from outside the peatland is a function of the surface topography, then lateral inputs could potentially be simulated by some topography-based flow modeling [e.g., Gedney and Cox, 2003]. However, in many regions where annual potential evapotranspiration minus precipitation is very small or even negative, e.g., boreal western Canada, it has been shown that external inputs of water are essential for peatlands and that the external input is not related to surface topography but rather to the complex structure of the underlying geology and surface deposits [Devito et al., 2005]. This situation is going to present a serious challenge for climate simulations given the current hydrology in climate models and the state of global data sets of underlying geology and surface deposits. Baird et al. [this volume] present a detailed discussion of spatial heterogeneity issues related to northern peatlands and outline a multiscale scheme for addressing them.

At the global scale, there have been a number of attempts to estimate and map the distribution of peatlands and wetlands [e.g., Matthews and Fung, 1987; Lehner and Döll, 2004]. These distributions are based on a combination of large-scale topographic modeling and globally mapped surface characteristics such as indices of inundation, soil properties, and vegetation. There have been attempts to simulate the distribution of wetlands using topographic wetness indexes. Kirkby et al. [1995] mapped the distribution of northern European wetlands using the topographic wetness index first proposed by Beven and Kirkby [1979]. Recently, Gedney and Cox [2003] used the same topographic index to simulate grid-scale runoff in a GCM and found improved estimates of global runoff (bias reduction from 37 to $25 \%$ ), improved estimates of precipitation (though not statistically significant improvements), and resulting patterns of saturated areas given by the topographic index (a new model result) that were consistent with major wetlands areas identified in the wetland distribution maps developed by Aselmann and Crutzen [1989]. Gedney and Cox [2003] concluded that any improvement in subgrid scale representation of soil moisture heterogeneity is an important step toward improving GCM projections of climate and hydrological changes.

The final aspect of hydrology in peatlands necessary to simulating the carbon balance is the transport/export of DOC. Multiyear observations of carbon balances on several peatlands have shown that the export of DOC is between 
10 and $20 \mathrm{~g} \mathrm{C} \mathrm{m}^{-2} \mathrm{a}^{-1}$, and this is the same order of magnitude as the long-term accumulation of organic matter in the peatlands [Roulet et al., 2007; Nilsson et al., 2008]. The production of DOC is a function of decomposition, but only a small fraction of the DOC produced is exported; the controls on DOC export are both hydrological and biogeochemical [Kalbitz et al., 2000]. Simulation of DOC export in peatland models has used a fixed DOC concentration and water export [Frolking et al., 2002], but this simply means DOC export tracks runoff, which is clearly not always the case [Fraser et al., 2001]. Yurova et al. [2007] developed a model based on convection and dispersion equations to simulate DOC concentration within a peatland and in peatland discharge. A simplified parameterization of export, based on this approach, might be found for coarse scale climate, carbon simulations. Moore [this volume] reviews DOC export from northern peatlands.

\subsection{Nonvascular Vegetation}

Plant functional types in peatlands are generally similar to those found in other terrestrial ecosystems, e.g., woody plants (deciduous and evergreen trees and shrubs), graminoids (sedges, rushes, grasses), forbs (other herbaceous plants), and bryophytes (nonvascular plants such as mosses and lichens). The primary differences between peatland and nonpeatland systems are that in peatlands (1) in some cases, bryophytes can account for a majority of total vegetation biomass and productivity [Moore et al., 2002], and (2) a fraction of the typical soil $0.5 \mathrm{~m}$ "root zone" [Jackson et $a l ., 1996]$ is often saturated, so plant rooting strategies and vertical root distributions may be different. The physiology of nonvascular plants is typically not represented in global carbon-climate models.

Bryophytes have no roots nor vascular system [Proctor, 2000], so land surface model developments related to soil moisture, root distributions, and leaf stomatal control on water and carbon exchanges [e.g., Sellers et al., 1997] are not directly relevant. Bryophyte metabolic rates are strongly related to their leaf water content [Proctor, 1982, 2000]; this presents a significant challenge to the vertical resolving power of climate model soil hydrology because bryophyte metabolism is sensitive to the water content of only the top few centimeters of the soil (peat and moss), rather than a thicker root zone. Bryophytes are also able to respond very quickly to changing environmental conditions, e.g., the seasonal temperature cycle and the subseasonal wetting and drying associated with weather patterns [Proctor, 1982, 2000], requiring new functions or algorithms for vegetation seasonal phenology. Bryophytes may be responsible for a significant fraction of the net ecosystem productivity in the "shoulder seasons," in early spring before vascular plants have emerged from their winter dormancy [Moore et al., 2006] and perhaps also in the autumn when vascular plants, particularly deciduous plants, have senesced. Lacking roots, algorithms for carbon allocation in bryophytes can be simpler than for vascular plants [e.g., Frolking et al., 2002].

Many peatlands are ombrotrophic, receiving the bulk of their nutrient inputs from wet and dry deposition. Mosses, which often develop a fairly complete ground cover under any emergent vascular vegetation, intercept and efficiently absorb much of wet nutrient deposition before it can percolate to the vascular root zone [e.g., Aerts et al., 1992; Malmer et al., 1994; Nordbakken et al., 2003]. Thus, the nutrients only become available to the vascular plants after they have cycled through the mosses and are re-mineralized during decomposition of moss litter. Limpens et al. [2003] found that nitrogen additions favored vascular plants and suppressed Sphagnum growth in greenhouse mesocosm studies. In the competition for light, vascular plants have the advantage because they can grow above the moss layer, although rapidly growing moss can engulf vascular seedlings [Limpens et al., 2003]. In a nutrient addition manipulation study on an ombrotrophic bog, Bubier et al. [2007] found that enhanced shrub growth shaded the underlying Sphagnum through increased leaf area and increased leaf litter fall; Sphagnum cover diminished substantially, but Polytrichum cover increased, and overall moss biomass diminished by about $50 \%$ over a 5 -year treatment period. They could not determine whether Polytrichum growth was due to nutrient enrichment or diminished competition from declining Sphagnum species. Shading and cooler moss temperature may also have had an impact [Bubier et al., 2007]. Pastor et al. [2002] presented a simple model of vegetation dynamics, simulating competition between a single vascular plant type and a single moss type. The model centers around access to different nutrient sources, wet deposition for mosses and mineralized nutrients for vascular plants. Moss and vascular plants also compete for other resources (e.g., light), simulated as a reduction in growth rate proportional to the biomass of the other plant type. This simple model generated nonlinear, dynamic behavior, and several different stable states can emerge that influence the capacity of the system to store and release carbon and nutrients. Frolking et al. [2001] used a simple model of peat accumulation to show that accumulation rates were sensitive to the fraction of total productivity generated by mosses and by vascular plants. Finally, bryophytes, and particularly Sphagnum species, play an important role in peat accumulation and peatland development, through their effects on the chemistry of peatland waters, their interactions with vascular plants, 
and their production of decay-resistant litter [Rydin et al., 2006].

Published data on above- and belowground vascular plant biomass and productivity for wetlands (peatlands, wet tundra, freshwater marsh, and salt marsh) show that wetlands, overall, have root biomass values and above- to belowground biomass ratios similar to those of nonforested systems (e.g., grasslands) [Jackson et al., 1996; Mokany et al., 2006; T. R. Moore, personal communication, 2008]. Wetlands generally have shallower root distributions than other terrestrial systems, and the below- to aboveground vascular plant biomass ratio for peatlands of $\sim 0.8$ (T. R. Moore, personal communication, 2008) is substantially higher than the root:shoot biomass ratios reported in Mokany et al. [2006] for boreal forests, i.e., $\sim 0.4$ for shoot biomass $>75 \mathrm{Mg} \mathrm{ha}^{-1}$ and $\sim 0.25$ for shoot biomass $<75 \mathrm{Mg} \mathrm{ha}^{-1}$ ). There is no indication whether or not the boreal forest data summarized in Mokany et al. [2006] included nonvascular biomass.

\subsection{Biogeochemistry}

Complete modeling of the peatland carbon cycle, and its impact on the global atmospheric burdens of $\mathrm{CO}_{2}$ and $\mathrm{CH}_{4}$, cannot be done without explicit or implicit representation of anaerobic decomposition of organic matter, and its impact on organic carbon accumulation rates, nutrient mineralization rates, nutrient availability, and methane emissions. A key challenge is to develop a comprehensive representation of the impacts of anaerobic conditions in the soil on all of these processes, along with a robust algorithm for the soil physics and hydrology that reliably simulates both the position of the water table, the peat water content above the water table, and the moss water content. This is not done at this time in any global coupled carbon-climate model.

Peatland methane emissions are the net of methane production and oxidation, and are influenced by transport mechanisms from peat to the atmosphere (diffusion, bubbling, plant-mediated transport). Peatland methane emissions have been modeled for the past decade or two, and insights from this work should be useful as climate models address these biogeochemical issues. Frolking and Crill [1994] modeled peat temperature and moisture profiles and correlated this to net methane flux. Granberg et al. [2001] and Kettunen [2003] extended this to modeling of plant productivity, methane production, oxidation, transport, and net flux. There are similarly constructed global-scale models of methane emissions from wetlands [e.g., Walter et al., 2001; Cao et al., 1996]. There have been studies with GCMS of climate change impacts on wetland methane emissions [e.g., Gedney and Cox, 2003; Shindell et al., 2004]; however, these studies have not directly incorporated the wetlands into the climate model, but have instead used GCM climate change projections to drive a model of wetland extent and methane emissions, again without a full simulation of the carbon cycle. There are peatland carbon cycle models that include anaerobic suppression of decomposition and vegetation productivity, but do not simulate methane production, oxidation, and transport [e.g., Frolking et al., 2002; Yurova et al., 2007; St-Hilaire et al., 2009]. There are several terrestrial biogeochemical models that simulate wetland biogeochemistry, including explicit or implicit representation of aerobic and anaerobic processes in the soil at varying levels of detail [e.g., DNDC, Zhang et al., 2002; Li et al., 2004; ecosys, Grant and Roulet, 2002; Biome-BGC, Bond-Lamberty et al., 2007; NASA-CASA, Potter et al., 2001; TEM, Zhuang et al., 2004]. These models can also simulate upland systems, but to date, they have not been applied to wetlands/peatlands at global scales, and only the TEM model has been applied at regional scales for a landscape mosaic of peatlands and uplands [Zhuang et al., 2004].

Gedney et al. [2004] used a GCM-driven topographic index estimation of saturated area (discussed in section 4.2 above) to simulate climate change impacts on $\mathrm{CH}_{4}$ emissions from wetlands. In this exercise, they calibrated the $\mathrm{CH}_{4}$ production rate and temperature sensitivity to match current global methane emissions and then estimated changes in wetland area and $\mathrm{CH}_{4}$ emissions over the period up to 2100 . A limitation to this approach is that it is essentially an estimate of inundated area, while many wetlands have water tables slightly below the surface, and the slight variations in the location of this water table has a significant impact on methane fluxes. Bubier et al. [2005] estimated a $60 \%$ increase in methane flux at the landscape scale due to small changes in water table depth $(2-5 \mathrm{~cm})$ and slight warming $\left(0.5^{\circ}\right)$ of small wetlands in a wet and a dry year. This variability, at large scales, has been suggested as a cause for observed interannual variability in the atmospheric methane burden over the past decade or two [Dlugokencky et al., 2001; Bousquet et al., 2006]. A difference of water table elevation from the surface to only $0.3 \mathrm{~m}$ depth is the difference between a peatland emitting a large amount of $\mathrm{CH}_{4}$ and very little or none (i.e., all the $\mathrm{CH}_{4}$ the peatland produces being oxidized) [Granberg et al., 1997]. Topographic index hydrological modeling [e.g., Beven and Kirkby, 1978] may not be sufficient to the task of simulating the subtle differences in water table depth in the relatively flat landscapes that are common in much of the domain of northern peatlands. However, the shallow groundwater modeling of Borren and Bleuten [2006] did simulate water table depth variability at relevant vertical resolution over a large peatland complex. This will be further complicated by the effect of melting permafrost and the subsequent changes in landscape topography, peatland 
hydrology, and ecosystem structure and function. At a site in northern Sweden, the melting of the permafrost has led to a several order of magnitude increase in $\mathrm{CH}_{4}$ emissions and significant changes in $\mathrm{CO}_{2}$ exchange and DOC export [Christensen et al., 2004; Malmer et al., 2005; Johansson et al., 2006], though the latter change was not as clear as that of $\mathrm{CH}_{4}$. How long this impact on carbon fluxes will persist is not known.

Another challenge for modeling peatlands is the range of soil $\mathrm{pH}$ that occurs across peatland types; peatland $\mathrm{pH}$ interacts with vegetation species composition, nutrient availability, and productivity [e.g., Bubier, 1995]. Perhaps the first order effects can be captured in a simple peatland classification (e.g., bog and fen) with model parameterizations specific to the vegetation types that dominate these broad classes, in a similar way to how GCMs would disaggregate forests into a few classes (evergreen or deciduous, needleleaved, or broad-leaved).

\subsection{Disturbance}

For many natural landscapes, disturbance by wind or fire plays an important role in determining landscape characteristics that are of central importance to the coupled climatecarbon system [e.g., Foster et al., 1998]. Northern peatland disturbances include fire (both natural and human-caused); flooding/inundation due to beaver activity, reservoir construction, or thermokarst activity associated with permafrost degradation; water table drawdown as peatlands are drained for forestry, agriculture, or peat extraction; pollution/nutrient deposition (e.g., nitrogen and sulfur deposition); and linear disturbances such as roads and seismic lines that can fragment peatlands and alter their hydrology [Turetsky and St. Louis, 2006]. Only a few of these disturbances are unique to peatlands. Many that are common to all ecosystems (fire, forestry and agriculture, atmospheric deposition) are beginning to be incorporated into global climate models. For example, GCM simulations planned for the fifth IPCC Assessment will include, to a degree that will vary from model to model, the dominant human land use activities of agriculture and forestry [e.g., Washington et al., 2008], along with radiative forcing from anthropogenic greenhouse gases. Simulation of their impacts on peatlands may follow after inclusion of peatlands in the models. Linear disturbances, beaver activity, peatland draining, and peat extraction are not likely to be included in climate models in the near future.

Fire is a dominant form of disturbance in boreal forest ecosystems [e.g., Stocks et al., 2002], and boreal fire recurrence intervals range from $<100$ to $\sim 1000$ years [Balshi et al., 2007]. In forests, severe fires have a significant impact on forest structure and age distribution [e.g., Oliver and
Larson, 1996] and thus on the forest's direct interactions with the climate system through surface albedo and roughness. Peatlands also can burn, and their fire regimes may be similar to upland boreal forests, at least in Central Canada [Turetsky et al., 2004]. This has not been well documented across the pan-boreal domain of northern peatlands, however, and little is known about the statistics of peatland burn severity [Turetsky et al., 2004]. Fire algorithms are dependent on fuel availability and near-surface soil moisture with different combustion efficiencies assumed for vegetation, litter, and root biomass [Thonicke et al., 2001; Thornton et al., 2007]. Parameterizations will need to be developed for peatland fires.

Thermokarst landscapes arise in regions where melting permafrost and draining water cause the ground to settle unevenly. There is evidence that the surface water conditions can change quickly as permafrost thaws and hydrological flow paths are modified [e.g., Jorgenson et al., 2006]. There is more evidence of thermokarst impacts on lakes because they are more easily detected in spaceborne remote sensing than peatlands, but the hydrological impacts on lakes will also apply to wetlands. Thermokarst (or thaw) lakes can form in permafrost regions when massive ground-ice wedges melt, causing the ground surface to subside and lakes to form. Further ground melting can eventually lead to drainage and disappearance of thermokarst lakes [Smith et al., 2005]. Riordan et al. [2006] found that the area and number of small water bodies in non-arctic Alaska decreased from 1950 to 2002, and attributed this change to increased drainage and or an increase in evapotranspiration. Soil thermal regimes and ground thaw are very dependent on soil thermal properties and water content, so a net drying (or wetting) of soils, particularly organic soils [e.g., Lawrence et al., 2008] will have an impact on permafrost formation and degradation rates. Modeling this dynamic nature of the land surface [e.g., West and Plug, 2008; Plug and West, 2009] may prove to be difficult in a GCM. In principal, a model could be structured to permit the fractional area of wetland and upland zones to evolve over time, although in practice, this may be technically challenging when it comes to maintaining water, energy, and carbon conservation as soil characteristics evolve.

\section{CONCLUDING COMMENTS}

Peatland carbon cycling is affected by weather and climate, and the Earth's climate system is affected by peatland carbon cycling. This inherent feedback suggests that peatlands should be incorporated into global climate models. However, northern peatlands have several unique characteristics that will make it difficult to represent their behavior 
in the Earth system within the vegetation classes of current global climate model land surface schemes. These characteristics include deep organic soils [a topic being addressed in current GCM model development; Lawrence and Slater, 2008], bryophyte vegetation, shallow water tables, and anoxic soil profiles, a high degree of spatial heterogeneity in vegetation and hydrology, and some unique disturbance/recovery characteristics. A primary requirement for a successful representation is for peatland distribution to correspond to wetland distribution, i.e., the peatlands form and persist where the land is wet. GCMs will need to be able to interrelate soil moisture heterogeneity with soil carbon heterogeneity. One potential solution is to split each grid cell into static wetland (peatland) and upland zones as is done in the TEM model [Zhuang et al., 2004]. Under this configuration, in wetland zones, carbon will accumulate, and peatlands can accumulate due to anoxic conditions that limit decomposition. A limitation to this approach is the inherent assumption of stationarity, e.g., that wetland distribution is fixed in time and does not respond to changes in the surface water balance (though changes in the surface water balance would alter water table depth within wetland zones). A more dynamic representation of peatlands would include peatland initiation (probably as paludification) and growth and development, where hydrology and peatland vegetation would interact, rather than being prescribed as coincident.

Global climate models have a global domain, and peatlands do not only occur in the north, though a large majority of peatland research to date has been in the boreal and temperate zones. Incorporating peatlands into global climate models will need to account for all peatlands, not just northern peatlands. Tropical peatlands occupy $\sim 0.3-0.6$ million $\mathrm{km}^{2}$, about $10 \%$ of the total global peatland area, and may contain $\sim 20 \%$ of global peat carbon [Charman, 2002; Page et al., 2002, 2004]. These tropical peatlands also have accumulated peat over millennia, often to depths $\sim 10 \mathrm{~m}$ [Page et al., 2004]. Many of the same issues will arise in representing tropical peatlands in global climate models (deep organic soils, shallow water tables and anoxia, potentially unique disturbance regimes, spatial heterogeneity); bryophytes probably play a less important role in most tropical peatlands than they do in northern peatlands [Page et al., 2006]. Before we can know how well a peatland land surface scheme successfully developed for northern peatlands will work for tropical peatlands, there is a need for more basic observational data from tropical peatlands, vegetation ecology, hydrology, biogeochemical cycling, and palynology.

Acknowledgments. We thank C.C. Treat, A.J. Baird, and one anonymous reviewer for comments on the manuscript. S.F. was supported by NSF grant ATM-0628399 and NASA IDS Program grant
NNX07AH32G. Funding for N.T.R. climate research was provided by the Natural Sciences and Engineering Research Council of Canada and the Canadian Foundation for Climate and Atmospheric Sciences. D.L. was supported by the U.S. DOE, Office of Science (BER), Cooperative Agreement DE-FC02-97ER62402.

\section{REFERENCES}

Aerts, R., B. Wallén, and N. Malmer (1992), Growth limiting nutrients in Sphagnum-dominated bogs subject to low and high atmospheric nitrogen supply, J. Ecol., 80, 131-140.

Aselmann, I., and P. J. Crutzen (1989), Freshwater wetlands: Global distribution of natural wetlands and rice paddies, their net primary productivity, seasonality and possible methane emissions, J. Atmos. Chem., 8, 307-358.

Aurela, M., T. Laurila, and J.-P. Tuovinen (2002), Annual $\mathrm{CO}_{2}$ balance of a subarctic fen in northern Europe: Importance of the wintertime efflux, J. Geophys. Res., 107(D21), 4607, doi:10.1029/2002JD002055.

Baird, A. J., L. R. Belyea, and P. J. Morris (2009), Upscaling peatland-atmosphere fluxes of methane: Small-scale heterogeneity in process rates and the pitfalls of "bucket-and-slab" models, Geophys. Monogr. Ser., doi:10.1029/2008GM000826, this volume.

Balshi, M. S., et al. (2007), The role of historical fire disturbance in the carbon dynamics of the pan-boreal region: A processbased analysis, J. Geophys. Res., 112, G02029, doi:10.1029/ 2006JG000380.

Belyea, L. R., and A. J. Baird (2006), Beyond "The limits to peat bog growth": Cross-scale feedback in peatland development, Ecol Monogr., 76, 299-322.

Beringer, J., A. H. Lynch, F. S. Chapin, M. Mack, and G. B. Bonan (2001), The representation of arctic soils in the land surface model: The importance of mosses, J. Climate, 14, 3324-3335.

Beven, K. J., and M. J. Kirkby (1979), A physically-based, variable contributing area model of basin hydrology, Hydrol. Sci. Bull., 24, 43-69.

Bobbink, R., M. Hornung, and J. G. M. Roelofs (1998), The effects of air-borne nitrogen pollutants on species diversity in natural and semi-natural European vegetation, J. Ecol., 86, 717-738.

Boelter, D. (1964), Water storage properties of several peats in situ, Soil Sci. Soc. Am. Proc., 28, 433-435.

Boelter, D. (1969), Physical properties of peats related to degree of decomposition, Soil Sci. Soc. Am. Proc., 33, 606-609.

Bonan, G. B. (2008), Forests and climate change: Forcings, feedbacks, and the climate benefits of forests, Science, 320, 1444-1449.

Bond-Lamberty, B., S. T. Gower, and D. E. Ahl (2007), Improved simulation of poorly drained forests using Biome-BGC, Tree Physiol., 27, 703-715.

Borren, W., and W. Bleuten (2006), Simulating Holocene carbon accumulation in a western Siberian watershed mire using a three-dimensional dynamic modeling approach, Water Resour. Res., 42, W12413, doi:10.1029/2006WR004885.

Bousquet, P., et al. (2006), Contribution of anthropogenic and natural sources to atmospheric methane variability, Nature, 443 , 439-443. 
Brouchkov, A., and M. Fukuda (2002), Preliminary measurements on methane content in permafrost, central Yakutia, and some experimental data, Permafrost Periglacial Processes, 3, 187-197.

Brovkin, V., J. Bendtsen, M. Claussen, A. Ganopolski, C. Kubatzki, V. K. Petoukhov, and A. Andreev (2002), Carbon cycle, vegetation and climate dynamics in the Holocene: Experiments with the CLIMBER-2 model, Global Biogeochem. Cycles, 16(4), 1139, doi:10.1029/2001GB001662.

Brovkin, V., J.-H. Kim, M. Hofmann, and R. Schneider (2008), A lowering effect of reconstructed Holocene changes in sea surface temperatures on the atmospheric $\mathrm{CO}_{2}$ concentration, Global Biogeochem. Cycles, 22, GB1016, doi:10.1029/2006GB002885.

Bubier, J. L. (1995), The relationship of vegetation to methane emission and hydrochemical gradients in northern peatlands, $J$. Ecol., 83, 403-420.

Bubier, J. L., T. R. Moore, L. Bellisario, N. T. Comer, and P. M. Crill (1995), Ecological controls on methane emissions from a Northern peatland complex in the zone of discontinuous permafrost, Manitoba, Canada, Global Biogeochem. Cycles, 9, 455470.

Bubier, J., T. Moore, K. Savage, and P. Crill (2005), A comparison of methane flux in a boreal landscape between a dry and a wet year, Global Biogeochem. Cycles, 19, GB1023, doi:10.1029/ 2004GB002351.

Bubier, J. L., T. R. Moore, and L. A. Bledzki (2007), Effects of nutrient addition on vegetation and carbon cycling in an ombrotrophic bog, Global Change Biol., 13, 1168-1186.

Camill, P., J. A. Lynch, J. S. Clark, J. B. Adams, and B. Jordan (2001), Changes in biomass, aboveground net primary production, and peat accumulation following permafrost thaw in the boreal peatlands of Manitoba, Canada, Ecosystems, 4, 461-478.

Cao, M., S. Marshall, and K. Gregson (1996), Global carbon exchange and methane emission from natural wetlands: Application of a process-based model, J. Geophys. Res., 101, 14,39914,414 .

Charman, D. (2002), Peatlands and Environmental Change, 301 pp., John Wiley, Chichester U. K.

Christensen, J. H., et al. (2007), Regional climate projections, in Climate Change 2007: The Physical Science Basis: Contribution of Working Group I to the Fourth Assessment Report of the Intergovernmental Panel on Climate Change, edited by S. Solomon et al., pp. 847-940, Cambridge Univ. Press, Cambridge, U. K.

Christensen, T. R., T. Johansson, H. J. Åkerman, M. Mastepanov, N. Malmer, T. Friborg, P. Crill, and B. H. Svensson (2004), Thawing sub-arctic permafrost: Effects on vegetation and methane emissions, Geophys. Res. Lett., 31, L04501, doi:10.1029/ 2003GL018680.

Clapp, R. B., and G. M. Hornberger (1978), Empirical equations for some soil hydraulic properties, Water Resour. Res., 14, 601-604.

Claussen, M., et al. (2002), Earth system models of intermediate complexity: Closing the gap in the spectrum of climate system models, Clim. Dyn., 18, 579-586.

Clymo, R. (1984), The limits of peat bog growth, Philos. Trans. $R$. Soc. London B, 303, 605-654.

Comer, N. T., P. Lafleur, N. T. Roulet, M. G. Letts, M. R. Skarupa, and D. L. Verseghy (2000), A test of the Canadian Land Surface
Scheme (CLASS) for a variety of wetland types, Atmos. Oceans, $38,161-179$.

Couwenberg, J., and H. Joosten (2005), Self-organization in raised bog patterning: The origin of microtope zonation and mesotope diversity, J. Ecol., 93, 1238-1248.

Cox, P. M., R. A. Betts, C. B. Bunton, R. L. H. Essery, P. R. Rowntree, and J. Smith (1999), The impact of new land surface physics on the GCM simulation of climate and climate sensitivity, Clim. Dyn., 15, 183-203.

Cox, P. M., R. A. Betts, C. D. Jones, S. A. Spall, and I .J. Totterdell (2000), Acceleration of global warming due to carbon-cycle feedbacks in a coupled climate model, Nature, 408, 184-187.

Davidson, E. A., and I. A. Janssens (2006), Temperature sensitivity of soil carbon decomposition and feedbacks to climate change, Nature, 440, 165-173.

Devito, K. J., I. F. Creed, and C. J. D. Fraser (2005), Controls on runoff from a partially harvested aspen-forested headwater catchment, Boreal Plain, Canada, Hydrol. Process., 19, 3-25.

Dlugokencky, E. J., B. P. Walter, K. A. Masarie, P. M. Lang, and E. S. Kasischke (2001), Measurements of an anomalous global methane increase during 1998, Geophys. Res. Lett., 28, 499502.

Evans, M. G., T. P. Burt, J. Holden, and J. K. Adamson (1999), Runoff generation and water table fluctuations in blanket peat: Evidence from UK data spanning the dry summer of $1995, J$. Hydrol., 221, 141-160.

Farouki, O. T. (1981), Thermal Properties of Soils, CRREL Monograph 81-1, 136 pp., U.S. Army Corps of Engineers, Cold Regions Research and Engineering Laboratory, Hanover, $\mathrm{NH}$.

Foster, D. R., D. H. Knight, and J. F. Franklin (1998), Landscape patterns and legacies resulting from large, infrequent forest disturbances, Ecosystems, 1, 497-510.

Fraser, C. J. D., N. T. Roulet, and P. M. Lafleur (2001), Groundwater flow patterns in a large peatland, J. Hydrol., 246, 142-154.

Friedlingstein, P., et al. (2006), Climate-carbon cycle feedback analysis: results from the C4MIP model intercomparison, $J$. Clim., 19, 3337-3353.

Frolking, S., and P. Crill (1994), Climate controls on temporal variability of methane flux from a poor fen in southeastern New Hampshire: Measurement and modeling, Global Biogeochem. Cycles, 8, 385-397.

Frolking, S., and N. T. Roulet (2007), Holocene radiative forcing impact of northern peatland carbon accumulation and methane emissions, Global Change Biol., 13, 1079-1088.

Frolking, S., N. T. Roulet, T. R. Moore, P. J. H. Richard, M. Lavoie, and S. D. Muller (2001), Modeling northern peatland decomposition and peat accumulation, Ecosystems, 4, 479-498.

Frolking, S., N. T. Roulet, T. R. Moore, P. Lafleur, J. L. Bubier, and P. M. Crill (2002), Modeling the seasonal to annual carbon balance of Mer Bleue Bog, Ontario, Canada, Global Biogeochem. Cycles, 16(3), 1030, doi:10.1029/2001GB001457.

Frolking, S., N. Roulet, and J. Fuglestvedt (2006), How northern peatlands influence the Earth's radiative budget: Sustained methane emission versus sustained carbon sequestration, J. Geophys. Res., 111, G01008, doi:10.1029/2005JG000091. 
Gedney, N., and P. M. Cox (2003), The sensitivity of global climate model simulations to the representation of soil moisture heterogeneity, J. Hydrometeorol., 4, 1265-1275.

Gedney, N., P. M. Cox, and C. Huntingford (2004), Climate feedback from wetland methane emissions, Geophys. Res. Lett., 31, L20503, doi:10.1029/2004GL020919.

Global Soil Data Task (2000), Global gridded surfaces of selected soil characteristics (IGBPDIS), http://www.daac.ornl.gov/, Distrib. Active Arch. Cent., Oak Ridge Natl. Lab., Oak Ridge, Tenn.

Gorham, E. (1991), Northern peatlands: role in the carbon cycle and probable responses to climatic warming, Ecol. Appl., 1, 182-195.

Gorham, E. (1995), The biogeochemistry of northern peatlands and its possible response to global warming, in Biotic Feedbacks in the Global Climatic System: will the warming speed the Warming?, edited by G. M. Woodwell and F. T. MacKenzie, pp. 169187, Oxford Univ. Press, New York.

Granberg, G., C. Mikkelä, I. Sundh, B. H. Svensson, and M. Nilsson (1997), Sources of spatial variation in methane emission from mires in northern Sweden-A mechanistic approach in statistical modeling, Global Biogeochem. Cycles, 11, 135150.

Granberg, G., M. Ottosson-Löfvenius, H. Grip, I. Sundh, and M. Nilsson (2001), Effect of climatic variability from 1980 to 1997 on simulated methane emission from a boreal mixed mire in northern Sweden, Global Biogeochem. Cycles, 15, 977991.

Grant, R. F., and N. T. Roulet (2002), Methane efflux from boreal wetlands: Theory and testing of the ecosystem model Ecosys with chamber and tower flux measurements, Global Biogeochem. Cycles, 16(4), 1054, doi:10.1029/2001GB001702.

Guertin, D. P., Barten. P. K.. and K. N. Brooks (1987), The peatland hvdrologic impact model: Development and testing, Nordic Hydrol., 18, 79-100.

Gunnarsson, U., H. Rydin, and H. Sjörs (2000), Diversity and pH changes after 50 years on the boreal mire Skattlosbergs Stormosse, Central Sweden, J. Veg. Sci., 11, 277-286.

Hillel, D. (1980), Fundamentals of Soil Physics, Elsevier, New York.

Ingram, H. A. P. (1978), Soil layers in mires: Function and terminology, J. Soil Sci., 29, 224-227.

Ito, A., and T. Oikawa (2002), A simulation model of the carbon cycle in land ecosystems Sim-CYCLE: A description based on dry-matter production theory and plot-scale validation, Ecol. Modell., 151, 147-179.

Jackson, R. B., J. Canadell, J. R. Ehleringer, H. A. Mooney, O. E. Sala, and E. D. Schulze (1996), A global analysis of root distributions for terrestrial biomes, Oecologia, 108, 389-411.

Joabsson, A., T. R. Christensen, and B. Wallen (1999), Vascular plant controls on methane emissions from northern peatforming wetlands, Trends Ecol. Evol., 14, 385-388.

Johansson, T., N. Malmer, P. M. Crill, T. Friborg, J. H. Åkerman, M. Mastepanov, and T. R. Christensen (2006), Decadal vegetation change in a northern peatland, greenhouse gas fluxes and net radiative forcing, Global Change Biol., 12, 2352-2369.
Jorgenson, M. T., Y. L. Shur, and E. R. Pullman (2006), Abrupt increase in permafrost degradation in Arctic Alaska, Geophys. Res. Lett., 33, L02503, doi:10:1029/2005GL024960.

Kalbitz, K., S. Solinger, J.-H. Park, B. Michalzik, and E. Matzner (2000), Controls on the dynamics of dissolved organic matter in soils: A review, Soil Sci., 165, 277-304.

Kettridge, N., and A. Baird (2007), In situ measurements of the thermal properties of a northern peatland: Implications for peatland temperature models, J. Geophys. Res., 112, F02019, doi:10.1029/2006JF000655.

Kettunen, A. (2003), Connection methane fluxes to vegetation cover and water table fluctuations at microsite level: A modeling study, Global Biogeochem. Cycles, 17(2), 1051, doi:10.1029/ 2002 GB001958.

King, J. Y., W. S. Reeburgh, and S. K. Regli (1998), Methane emission and transport by arctic sedges in Alaska: Results of a vegetation removal experiment, J. Geophys. Res., 103, 29083-29092.

Kirkby, M. J., P. E. Kneale, S. L. Lewis, and R. T. Smith (1995), Modelling the form and distribution of peat mires, in Hydrology and Hydrochemistry of British Wetlands, edited by J. M. R. Hughes and A. L. Heathwaite, pp. 83-94, John Wiley, Chichester, U. K.

Konyha, K. D., K. D. Robbins, and R. W. Skaggs (1988), Evaluating peat mining hydrology using DRAINMOD, J. Irrig. Drain., 114, 490-504.

Lafleur, P. M., N. T. Roulet, J. L. Bubier, S. Frolking, and T. R. Moore (2003), Interannual variability in the peatland-atmosphere carbon dioxide exchange at an ombrotrophic bog, Global Biogeochem. Cycles, 17(2), 1036, doi:10.1029/2002GB001983.

Laine, J., H. Vasander, and R. Laiho (1995), Long-term effects of water level drawdown on the vegetation of drained pine mires in southern Finland, J. Appl. Ecol., 32, 785-802.

Laine, J., J. Silvola, K. Tolenen, J. Alm, H. Nykänen, H. Vasander, T. Sallantaus, I. Savolainen, J. Sinisalo, and P. Marikainen (1996), Effect of water-level drawdown on global climatic warming: Northern peatlands, Ambio, 25, 179-184.

Lawrence, D. M., and A. G. Slater (2008), Incorporating organic soil into a global climate model, Clim. Dyn., 30, 145-160.

Lawrence, D. M., A. G. Slater, V. E. Romanovsky, and D. J. Nicolsky (2008), Sensitivity of a model projection of near-surface permafrost degradation to soil column depth and representation of soil organic matter, J. Geophys. Res., 113, F02011, doi:10.1029/ 2007JF000883.

Lehner, B., and P. Döll (2004), Development and validation of a global database of lakes, reservoirs and wetlands, J. Hydrol., 296, 1-22.

Le Treut, H., R. Somerville, U. Cubasch, Y. Ding, C. Mauritzen, A. Mokssit, T. Peterson, and M. Prather (2007), Historical overview of climate change, in Climate Change 2007: The Physical Science Basis: Contribution of Working Group I to the Fourth Assessment Report of the Intergovernmental Panel on Climate Change, edited by S. Solomon et al., pp. 93-127, Cambridge Univ. Press, Cambridge, U. K.

Letts, M. G., N. T. Roulet, N. T. Comer, M. R. Skarupa, and D. L. Verseghy (2000), Parameterization of peatland hydraulic properties for the Canadian Land Surface Scheme, Atmos. Ocean, 38, $141-160$. 
Li, C., J. Cui, G. Sun, and C. Trettin (2004), Modeling impacts of management on carbon sequestration and trace gas emissions in forested wetland ecosystems, Environ. Manag., 33, 176186.

Limpens, J., F. Berendse, and H. Klees (2003), N deposition affects $\mathrm{N}$ availability in interstitial water, growth of Sphagnum and invasion of vascular plants in bog vegetation, New Phytol., 157, 339-347.

MacDonald, J. A., D. Fowler, K. J. Hargreaves, U. Skiba, I. D. Leith, and M. B. Murray (1998), Methane emission rates from a northern wetland; response to temperature, water table and transport, Atmos. Environ., 32, 3219-3227.

Malmer, N., B. M. Svensson, and B. Wallén (1994), Interactions between Sphagnum mosses and field layer vascular plants in the development of peat-forming systems, Folia Goebot. Phytotax., Praha, 29, 483-496.

Malmer, N., T. Johansson, and T. R. Christensen (2005), Vegetation, climate changes, and net carbon sequestration in a Northern-Scandinavian subarctic mire over 30 years, Global Change Biol., 11, 1895-1109.

Matthews, E., and I. Fung (1987), Methane emission from natural wetlands: global distribution, area, and environmental characteristics of sources, Global Biogeochem. Cycles, 1, 61-86.

Meehl, G. A., et al. (2007), Global climate projections, in Climate Change 2007: The Physical Science Basis: Contribution of Working Group I to the Fourth Assessment Report of the Intergovernmental Panel on Climate Change, edited by S. Solomon et al., pp. 747-845, Cambridge Univ. Press, Cambridge, U. K.

Minkkinen, K., H. Vasander, S. Jauhiainen, S. Karsisto, and J. Laine (1999), Post-drainage changes in vegetation composition and carbon balance in Lakkasuo mire, Central Finland, Plant Soil, 207, 107-120.

Minkkinen, K., R. Korhonen, I. Savolainen, and J. Laine (2002), Carbon balance and radiative forcing of Finnish peatlands 19002100 - The impact of forestry drainage, Global Change Biol., $8,785-799$.

Mitsch, W. J., and J. G. Gosselink (2007), Wetlands, 4th ed., 600 pp., John Wiley, New York.

Mokany, K., R. J. Raison, and A. S. Prokushkini (2006), Critical analysis of root:shoot ratios in terrestrial ecosystems, Global Change Biol., 12, 84-96.

Moore, T. R. (2009), Dissolved organic carbon production and transport in Canadian peatlands, Geophys. Monogr. Ser., doi: 10.1029/2008GM000816, this volume.

Moore, T. R., N. T. Roulet, and J. M. Waddington (1998), Uncertainty in predicting the effect of climatic change on the carbon cycling of Canadian peatlands, Clim. Change, 40, 229-245.

Moore, T. R., J. L. Bubier, S. Frolking, P. Lafleur, and N. T. Roulet (2002), Plant biomass and production and $\mathrm{CO}_{2}$ exchange in an ombrotrophic bog, J. Ecol., 90, 25-36.

Moore, T. R., P. M. Lafleur, D. M. I. Poon, B. W. Heumann, J. W. Seaquist, and N. T. Roulet (2006), Spring photosynthesis in a cool temperate bog, Global Change Biol., 12, 2323-2335.

Nilsson, M., J. Sagerfors, I. Buffam, H. Laudon, T. Eriksson, A. Grelle, L. Klemedtsson, P. Weslien, and A. Lindroth (2008), Contemporary carbon accumulation in a boreal oligotrophic minerogenic mire-A significant sink after accounting for all Cfluxes, Global Change Biol., 14, 2317-2332.

Niu, G.-Y., Z.-L. Yang, R. E. Dickinson, and L. E. Gulden (2005), A simple TOPMODEL-based runoff parameterization (SIMTOP) for use in global climate models, J. Geophys. Res., 110, D21106, doi:10.1029/2005JD006111.

Nordbakken, J. F., M. Ohlson, and P. Hogberg (2003), Boreal bog plants: Nitrogen sources and uptake of recently deposited nitrogen, Environ. Pollut., 126, 191-200.

Oliver, C. D., and B. C. Larson (1996), Forest Stand Dynamics, updated ed., 520 pp., John Wiley, New York.

Paavilainen, E., and J. Päivänen (1995), Peatland Forestry: Ecology and Principles, 248 pp., Springer, Berlin.

Page, S. E., F. Siegert, J. O. Rieley, H.-D. V. Boehm, A. Jayak, and S. Limink (2002), The amount of carbon released from peat and forest fires in Indonesia during 1997, Nature, 420, 61-65.

Page, S. E., R. A. J. Wüst, D. Weiss, J. O. Rieley, W. Shotyk, and S. H. Limin (2004), A record of Late Pleistocene and Holocene carbon accumulation and climate change from an equatorial peat bog (Kalimantan, Indonesia): Implications for past, present and future carbon dynamics, J. Quat. Sci., 19, 625-635.

Page, S. E., J. O. Rieley, and R. Wüst (2006), Lowland tropical peatlands of Southeast Asia, in Peatlands: Evolution and Records of Environmental and Climate Change, edited by I. P. Martini, A. Martinez Cortizas, and W. Chesworth, pp. 145-171, Elsevier, Amsterdam, Netherlands.

Pastor, J., B. Peckham, S. Bridgham, J. Weltzin, and J. Q. Chen (2002), Plant community dynamics, nutrient cycling, and alternative stable equilibria in peatlands, Am. Nat., 160, 553-568.

Pauwels, V. R. N., and E. F. Wood (1999a), A soil-vegetationatmosphere transfer scheme for the modeling of water and energy balance processes in high latitudes: 1 . Model improvements, $J$. Geophys. Res., 104, 27,811-27,822.

Pauwels, V. R. N., and E. F. Wood (1999b), A soil-vegetationatmosphere transfer scheme for the modeling of water and energy balance processes in high latitudes: 2. Application and validation, J. Geophys. Res., 104, 27,823-27,839.

Petrone, R. M., J. M. Waddington, and J. S. Price (2001), Ecosystem scale evapotranspiration and net $\mathrm{CO}_{2}$ exchange from a restored peatland, Hydrol. Process., 15, 2839-2845.

Pitman, A. J. (2003), The evolution of, and revolution in, land surface schemes designed for climate models, Int. J. Climatol., 23, 479-510.

Plug, L. J., and J. J. West (2009), Thaw lake expansion in a twodimensional coupled model of heat transfer, thaw subsidence, and mass movement, J. Geophys. Res., 114, F01002, doi:10.1029/ 2006JF000740.

Potter, C., J. Bubier, P. Crill, and P. Lafleur (2001), Ecosystem modeling of methane and carbon dioxide fluxes for boreal forest sites, Can. J. For. Res., 31, 208-223.

Prather, M., et al. (2001), Atmospheric chemistry and greenhouse gases, in Climate Change 2001: The Scientific Basis: Contribution of Working Group I to the Third Assessment Report of the Intergovernmental Panel on Climate Change, edited by J. T. Houghton et al., pp. 239-287, Cambridge Univ. Press, Cambridge, U. K. 
Proctor, M. C. F. (1982), Physiological ecology: water relations, light and temperature responses, carbon balance, in Bryophyte Ecology, edited by A. J. E. Smith, pp. 333-382, CRC Press, London.

Proctor, M. C. F. (2000), Physiological ecology, in Bryophyte Biology, edited by A. W. Shaw and B. Goffinet, pp. 225-247, Cambridge Univ. Press, Cambridge, U. K.

Randall, D. A., et al. (2007), Climate Models and Their Evaluation, in Climate Change 2007: The Physical Science Basis: Contribution of Working Group I to the Fourth Assessment Report of the Intergovernmental Panel on Climate Change, edited by S. Solomon et al., pp. 589-662, Cambridge Univ. Press, Cambridge, U. K.

Riordan, B., D. Verbyla, and A. D. McGuire (2006), Shrinking ponds in subarctic Alaska based on 1950-2002 remotely sensed images, J. Geophys. Res., 111, G04002, doi:10.1029/2005JG000150.

Rivkina, E., D. Gilichinsky, S. Wagener, J. Tiedje, and J. McGrath (1998), Biogeochemical activity of anaerobic microorganisms from buried permafrost sediments, Geomicrobiology, 15, 187-193.

Rivkina, E., K. Laurinavichius, J. McGrath, J. Tiedje, V. Shcherbakova, and D. Gilichinsky (2004), Microbial life in permafrost, Adv. Space Res., 33, 1215-1221.

Rivkina, E., V. Shcherbakova, K. Laurinavichius, L. Petrovskaya, K. Krivushin, G. Kraev, S. Pecheritsina, and D. Gilichinsky (2007), Biogeochemistry of methane and methanogenic archaea in permafrost, FEMS Microbiol. Ecol., 61, 1-15.

Roulet, N. T., P. M. Lafleur, P. J. H. Richard, T. R. Moore, E. R. Humphreys, and J. L. Bubier (2007), Contemporary carbon balance and late Holocene carbon accumulation in a northern peatland, Global Change Biol., 13, 397-411.

Rydin, H., and J. Jeglum (2006), The Biology of Peatlands, 343 pp., Oxford Univ. Press, Oxford, U. K.

Rydin, H., U. Gunnarsson, and S. Sundberg (2006), The role of Sphagnum in peatland development and persistence, in Boreal Peatland Ecosystems, edited by R. K. Wieder and D. H. Vitt, pp. 47-65, Springer, New York.

Sellers, P. J., et al. (1997), Modeling the exchanges of energy, water, and carbon between continents and the atmosphere, Science, $275,502-509$.

Serreze, M. C., and J. A. Francis (2006), The arctic amplification debate, Clim. Change, 76, 241-264.

Shindell, D. T., B. P. Walter, and G. Faluvegi (2004), Impacts of climate change on methane emissions from wetlands, Geophys. Res. Lett., 31, L21202, doi:10.1029/2004GL021009.

Smith, L. C., G. M. MacDonald, A. A. Velichko, D. W. Beilman, O. K. Borisova, K. E. Frey, K. V. Kremenetski, and Y. Sheng (2004), Siberian peatlands a net carbon sink and global methane source since the early Holocene, Science, 303, 353-356.

Smith, L. C., Y. Sheng, G. M. MacDonald, and L. D. Hinzman (2005), Disappearing Arctic lakes, Science, 308, 1429.

Smith, L. C., Y. Sheng, and G. M. Macdonald (2007), A first panArctic assessment of the influence of glaciation, permafrost, topography and peatlands on northern hemisphere lake distribution, Permafrost Periglacial Processes, 18, 201-208.

Sonnentag, O., J. M. Chen, N. T. Roulet, W. Ju, and A. Govind (2008), Spatially explicit simulation of peatland hydrology and carbon dioxide exchange: The influence of mesoscale topography, J. Geophys. Res., 113, G02005, doi:10.1029/2007JG000605.

St-Hilaire, F., J. H. Wu, N. T. Roulet, S. Frolking, P. M. Lafleur, E. R. Humphreys, and V. Arora (2009), McGill Wetland Model: Evaluation of a peatland carbon simulator developed for global assessments, Biogeosciences, in press.

Stocks, B. J., et al. (2002), Large forest fires in Canada, 19591997, J. Geophys. Res., 108, 8149, doi:10.1029/2001JD000484, [printed 108(D1), 2003].

Tarnocai, C. (2006), The effect of climate change on carbon in Canadian peatlands, Global Planet. Change, 53, 222-232.

Tempel, P., N. H. Batjes, and V. W. P. van Engelen (1996), IGBPDIS soil data set for pedotransfer function development, Working Pap. Preprint 96/06, Int. Soil Ref. and Inf. Cent., Wageningen, Netherlands. (Available at http://www.isric.org/UK/About+Soils/ Soil+data/)

Thonicke, K., S. Venevsky, S. Sitch, and W. Cramer (2001), The role of fire disturbance for global vegetation dynamics: Coupling fire into a Dynamic Global Vegetation Model, Global Ecol. Biogeogr., 10, 661-667.

Thornton, P. E., and N. A. Rosenbloom (2005), Ecosystem model spin-up: Estimating steady state conditions in a coupled terrestrial carbon and nitrogen cycle model, Ecol. Modell., 189, 25-48.

Thornton, P. E., J.-F. Lamarque, N. A. Rosenbloom, and N. M. Mahowald (2007), Influence of carbon-nitrogen cycle coupling on land model response to $\mathrm{CO}_{2}$ fertilization and climate variability, Global Biogeochem. Cycles, 21, GB4018, doi:10.1029/ 2006GB002868.

Tolonen, K., H. Vasander, A. W. H. Damman, and R. S. Clymo (1992), Preliminary estimate of long-term carbon accumulation and loss in 25 boreal peatlands, Suo, 43, 277-280.

Treat, C. C., J. L. Bubier, R. K. Varner, and P. M. Crill (2007), Timescale dependence of environmental and plant-mediated controls on $\mathrm{CH}_{4}$ flux in a temperate fen, J. Geophys. Res., 112, G01014, doi:10.1029/2006JG000210.

Trumbore, S. E., and C. I. Czimczik (2008), An uncertain future for soil carbon, Science, 321, 1455-1456.

Tuittila, E.-S., H. Vasander, and J. Laine (2003), Success of reintroduced Sphagnum in a cut-away peatland, Boreal Environ. Res., 8, 245-250.

Turetsky, M. R., and V. L. St. Louis (2006), Disturbance in boreal peatlands, in Boreal Peatland Ecosystems, edited by R. K. Wieder and D. H. Vitt, pp. 359-380, Springer, Berlin.

Turetsky, M. R., B. D. Amiro, E. Bosch, and J. S. Bhatti (2004), Historical burn area in western Canadian peatlands and its relationship to fire weather indices, Global Biogeochem. Cycles, 18, GB4014, doi:10.1029/2004GB002222.

Turunen, J., E. Tomppo, K. Tolonen, and A. Reinikainen (2002), Estimating carbon accumulation rates of undrained mires in FinlandApplication to boreal and subarctic mires, Holocene, 12, 79-90.

Verry, E. S., and D. H. Boelter (1978), Peatland hydrology, in Wetland Functions and Values: The State of Our Understanding, Proceedings of the National Symposium on Wetlands, pp. 389-402, Am. Water Resour. Assoc., Minneapolis, Minn.

Verry, E. S., K. N. Brooks, and P. K. Barten (1988), Streamflow response from an ombrotrophic mire, in Proceedings of the Inter- 
national Symposium on the Hydrology of Wetlands in Temperate and Cold Regions, pp. 51-59, Acad. of Finland, Helsinki.

Vitt, D. H. (2006), Functional characteristics and indicators of boreal peatlands, in Boreal Peatland Ecosystems, edited by R. K. Wieder and D. H. Vitt, pp. 9-24, Springer, New York.

Waddington, J. M., N. T. Roulet, and R. V. Swanson (1996), Water table control of $\mathrm{CH}_{4}$ emission enhancement by vascular plants in boreal peatlands, J. Geophys. Res., 101, 22,775-22,785.

Walmsley, M. E. (1977), Physical and chemical properties of peat, in Muskeg and the Northern Environment in Canada, edited by N. W. Radforth and C. O. Brawner, pp. 82-129, Univ. of Toronto Press, Toronto, Ont., Canada.

Walter, B. P., M. Heimann, and E. Matthews (2001), Modeling modern methane emissions from natural wetlands: 1 . Model description and results, J. Geophys. Res., 106, 34,189-34,206.

Wang, Y., L. A. Mysak, and N. T. Roulet (2005), Holocene climate and carbon cycle dynamics: Experiments with the 'green' McGill Paleoclimate Model, Global Biogeochem. Cycles, 19, GB3022, doi:10.1029/2005GB002484.

Washington, W. M., J. Drake, L. Buja, D. Anderson, D. Bader, R. Dickinson, D. Erickson, P. Gent, S. Ghan, P. Jones, et al. (2008), The use of the Climate-Science Computational End Station (CCES) development and grand challenge team for the next IPCC assessment: An operational plan, J. Phys. Conf. Ser., 125, doi:10.1088/1742-6596/125/1/012024.

Weiss, R., N. J. Shurpali, T. Sallantaus, R. Laiho, J. Laine, and J. Alm (2006), Simulation of water table level and peat temperatures in boreal peatlands, Ecol. Modell., 192, 441-456.

West, J. J., and L. J. Plug (2008), Time-dependent morphology of thaw lakes and taliks in deep and shallow ground ice, J. Geophys. Res., 113, F01009, doi:10.1029/2006JF000696.

Whiting, G. J., and J. P. Chanton (1993), Primary production control of methane emissions from wetlands, Nature, 364, 794-795.

Whiting, G. J., and J. P. Chanton (2001), Greenhouse carbon balance of wetlands: Methane emission versus carbon sequestration, Tellus, Ser. B, 53, 521-528.

Wickland, K. P., R. G. Striegl, J. C. Neff, and T. Sachs (2006), Effects of permafrost melting on $\mathrm{CO}_{2}$ and $\mathrm{CH}_{4}$ exchange of a poorly drained black spruce lowland, J. Geophys. Res., 111, G02011, doi:10.1029/2005JG000099.

Wieder, R. K., and D. H. Vitt (Eds.) (2006), Boreal Peatland Ecosystems, 435 pp., Springer, Berlin.

Wieder, R. K., D. H. Vitt, and B. W. Benscoter (2006), Peatlands and the boreal forest, in Boreal Peatland Ecosystems, edited by R. K. Wieder and D. H. Vitt, pp. 1-8, Springer, New York.

Yi, S., M. A. Arain, and M.-K. Woo (2006), Modifications of a land surface scheme for improved simulation of ground freezethaw in northern environments, Geophys. Res. Lett., 33, L13501, doi:10.1029/2006GL026340.

Yi, S., M. Woo, and M. A. Arain (2007), Impacts of peat and vegetation on permafrost degradation under climate warming, Geophys. Res. Lett., 34, L16504, doi:10.1029/2007GL030550.
Yoshikawa, C., M. Kawamiya, T. Kato, Y. Yamanaka, and T. Matsuno (2008), Geographical distribution of the feedback between future climate change and the carbon cycle, J. Geophys. Res., 113, G03002, doi:10.1029/2007JG000570.

Yu, Z., D. H. Vitt, I. D. Campbell, and M. J. Apps (2003), Understanding Holocene peat accumulation pattern of continental fens in western Canada, Can. J. Bot., 81, 267-282.

Yurova, A. Y., and H. Lankreijera (2007), Carbon storage in the organic layers of boreal forest soils under various moisture conditions: A model study for Northern Sweden sites, Ecol. Modell., 204, 475-484.

Yurova, A., A. Wolf, J. Sagerfors, and M. Nilsson (2007), Variations in net ecosystem exchange of carbon dioxide in a boreal mire: Modeling mechanisms linked to water table position, $J$. Geophys. Res., 112, G02025, doi:10.1029/2006JG000342.

Zhang, Y., C. Li, C. C. Trettin, H. Li, and G. Sun (2002), An integrated model of soil, hydrology, and vegetation for carbon dynamics in wetland ecosystems, Global Biogeochem. Cycles, 16(4), 1061, doi:10.1029/2001GB001838.

Zhang, Y., W. Chen, and D. W. Riseborough (2006), Temporal and spatial changes of permafrost in Canada since the end of the Little Ice Age, J. Geophys. Res., 111, D22103, doi:10.1029/ 2006JD007284.

Zhuang, Q., J. M. Melillo, D. W. Kicklighter, R. G. Prinn, A. D. McGuire, P. A. Steudler, B. S. Felzer, and S. Hu (2004), Methane fluxes between terrestrial ecosystems and the atmosphere at northern high latitudes during the past century: A retrospective analysis with a process-based biogeochemistry model, Global Biogeochem. Cycles, 18, GB3010, doi:10.1029/2004GB002239.

Zimov, S. A., S. P. Davydov, G. M. Zimova, A. I. Davydova. E. A. G. Schuur, K. Durra, and F. S. Chapin III (2006), Permafrost carbon: Stock and decomposability of a globally significant carbon pool, Geophys. Res. Lett., 33, L20502, doi.10.1029/ 2006 GL027484.

Zoltai, S. C. (1993), Cyclic development of permafrost in the peatlands of northwestern Alberta, Canada, Arct. Alp. Res., 25, 240-246.

Zoltai, S. C., R. M. Siltanen, and J. D. Johnson (2000), A wetland database for the western boreal, subarctic, and arctic regions of Canada, Inf. Rep. NOR-X-368, North. For. Cent., Can. For. Serv., Edmonton, Alberta, Canada.

S. Frolking, Complex Systems Research Center, Institute for the Study of Earth Oceans and Space, 8 College Road, University of New Hampshire, Durham, NH 03824, USA. (steve.frolking@ unh.edu)

D. Lawrence, Climate and Global Dynamics Division, National Center for Atmospheric Research, Boulder, CO 80305, USA.

N. Roulet, Department of Geography and McGill School of the Environment, McGill University, Montreal, QC H3A 2K6, Canada. 